\title{
Pengaruh Model Pembelajaran Experiential Learning terhadap Kemampuan Pemecahan Masalah Mahasiswa Geografi
}

\author{
Tifani Yuniar Priyandari ${ }^{1}$, I Komang Astina ${ }^{1}$, Dwiyono Hari Utomo ${ }^{1}$ \\ ${ }^{1}$ Pendidikan Geografi-Universitas Negeri Malang
}

\section{INFO ARTIKEL}

Riwayat Artikel:

Diterima: 11-06-2019

Disetujui: 14-01-2020

\section{Kata kunci:}

experiential learning model; problem solving skills; model pembelajaran experiential learning;

kemampuan pemecahan masalah

\author{
Alamat Korespondensi: \\ Tifani Yuniar Priyandari \\ Pendidikan Geografi \\ Universitas Negeri Malang \\ Jalan Semarang 5 Malang \\ E-mail: tifaniyuniar28@gmail.com
}

\begin{abstract}
ABSTRAK
Abstract: Problem solving skills must be possessed by every student to solve problems by involving critical, logical and systematic thinking. This study aims to determine the effect of Experiential Learning on students' problem solving skills. This study used a quasi experiment method with a pretest-posttest control design. The subjects in this study were geography students, with 68 students in total from two homogeneous classes. Data collection technique used instruments in the form of essay test to measure students' problem solving skills. The results present that there is a significant effect of Experiential Learning on students' problem solving skills.

Abstrak: Kemampuan pemecahan masalah harus dimiliki oleh setiap mahasiswa untuk menyelesaikan permasalahan dengan melibatkan pemikiran yang kritis, logis dan sistematis. Penelitian ini bertujuan untuk mengetahui pengaruh model pembelajaran Experiential Learning terhadap kemampuan pemecahan masalah mahasiswa. Penelitian ini menggunakan metode quasi experiment dengan rancangan pretest-posttest control design. Subjek dalam penelitian ini adalah mahasiswa geografi sebanyak 68 mahasiswa pada dua kelas yang bersifat homogen. Teknik pengumpulan data menggunakan instrumen berupa soal esai untuk mengukur kemampuan pemecahan masalah. Hasil penelitian menunjukkan terdapat pengaruh signifikan model pembelajaran Experiential Learning terhadap kemampuan pemecahan masalah mahasiswa.
\end{abstract}

Kemampuan pemecahan masalah harus dimiliki oleh setiap mahasiswa. Menurut Jogiyanto (2016),pemecahan masalah adalah upaya perseorangan atau kelompok untuk menemukan jawaban berdasarkan pemahaman yang telah dimiliki dalam rangka memenuhi tuntutan situasi yang tidak sesuai dengan harapan. Kegiatan pemecahan masalah adalah kemampuan dasar yang harus dimiliki oleh mahasiswa dalam menyelasaikan permasalahan dengan melibatkan pemikiran yang kritis, logis dan sistematis. Kemampuan pemecahan masalah perlu ditanamkan ke mahasiswa melalui kegiatan pembelajaran aktif (active learning). Pembelajaran aktif dilandaskan pada pandangan konstruktivisme yang menekankan belajar berorientasi pada pemecahan masalah untuk mendorong mahasiswa secara aktif melakukan sesuatu agar mentransformasi informasi menjadi pengetahuan (Kumara, 2004). Pengetahuan mahasiswa tidak diperoleh dari sumber eksternal seperti dalam model ceramah, melainkan dari aktivitasaktivitas yang dilakukan oleh mereka sendiri. Keterlibatan aktif mahasiswa akan membangun kemampuan kognitifnya dalam berpikir secara kritis, logis, dan sistematis dalam memecahkan berbagai permasalahan terkait materi pembelajaran.

Salah satu bentuk pembelajaran aktif yang dapat mengembangkan kemampuan pemecahan masalah mahasiswa adalah Experiantal Learning. Experiential Learning merupakan model pembelajaran berbasis pengalaman yang dapat menciptakan proses pembelajaran yang lebih bermakna. Model Experiential Learning adalah suatu model pembelajaran yang mengaktifkan proses pembelajaran untuk membangun pengetahuan dan keterampilan melalui pengalaman secara langsung (Sholihah, 2016). Model pembelajaran ini memungkinkan mahasiswa untuk tidak hanya membayangkan sebuah fenomena atau kemungkinankemungkinan yang dapat terjadi terkait dengan fenomena tersebut, tetapi juga secara langsung mengalaminya sebagai bagian dari proses pembelajaran. Model Experiential Learning melibatkan siswa secara langsung dalam masalah atau isu yang dipelajari (Lestari, Sadia, \& Suma, 2014). Melalui model pembelajaran ini, mahasiswa dapat secara efektif belajar melalui pengalaman- 
pengalamannya sendiri. Pembelajaran Experiential Learning tepat diterapkan dalam pembelajaran Geografi Lingkungan untuk mengembangkan kemampuan pemecahan masalah mahasiswa. Hal ini terkait dengan materi dalam Geografi Lingkungan yang mengintegrasikan geografi fisik dan geografi manusia, yakni melibatkan berbagai aspek hubungan timbal balik antara manusia dengan lingkungan dalam memahami perubahan lingkungan secara global.

Pembelajaran Geografi Lingkungan tidak lepas dari permasalahan-permasalahan lingkungan yang timbul akibat pengaruh dari aktivitas manusia, terutama terkait eksploitasi sumberdaya yang berlebihan dan pengelolaan lingkungan yang tidai sesuai dengan ketentuan. Melalui kegiatan pemecahan masalah, mahasiswa diharapkan bisa lebih peka terhadap permasalahan lingkungan di sekitar mereka berdasarkan aspek-aspek keruangannya, mampu menggunakan kemampuan berpikirnya untuk merumuskan permasalahan-permasalahan yang ada dan menentukan solusi yang paling efektif untuk memecahkannya. Model Experiential Learning pertama kali diperkenalkan oleh David A. Kolb. (Kolb, 1984) menyatakan dalam bukunya "Experiential Learning: Experience as the Source of Learning and Development" bahwa pembelajaran adalah sebuah proses di mana konsepkonsep didapatkan dan dimodifikasi secara terus menerus melalui pengalaman. Experiential Learning adalah model pembelajaran yang dilandaskan keyakinan bahwa pengetahuan dibentuk dari transformasi pengalaman. Model pembelajaran ini mencakup dua proses pemahaman pengalaman, yaitu Concrete Experience (AC) dan Abstract Conceptualization (AC), dan dua proses transformasi pengalaman, yaitu Reflective Observation (RO) dan Active Experientation (RO) (Kolb \& Kolb, 2005). Experiential Learning merupakan proses pembentukan pengetahuan yang memungkinkan mahasiswa untuk menyentuh keempat aspek dasar dalam belajar, yaitu mengalami, merefleksikan, berpikir, dan melakukan tindakan terkait dengan isu yang dipelajari. Pengalaman konkret dijadikan sebagai dasar untuk melakukan observasi dan refleksi. Hasil dari refleksi dicerna dan diproses menjadi konsep abstrak yang kemudian dikembangkan menjadi implikasi untuk pengambilan tindakan. Implikasi-implikasi tersebut dapat diujikan dan dijadikan sebagai arahan untuk menciptakan pengalaman baru.

Keunggulan Experiential Learning didukung oleh hasil penelitian (Mustika, 2015) yang didapatkan dengan meneliti pengaruh Experiential Learning terhadap kemampuan berpikir kritis mahasiswa. Mustika menemukan bahwa Experiential Learning memiliki potensi untuk meningkatkan keaktifan belajar mahasiswa dan meningkatkan kemampuan pemecahan masalah. Hal ini dibuktikan melalui data hasil observasi keterlaksanaan SAP dan tabel nilai rata-rata kemampuan berpikir kritis mahasiswa. Hal serupa juga dikemukakan oleh Sholihah (2016) melalui hasil penelitiannya yang menunjukkan bahwa Experiental Learning berpengaruh signifikan terhadap kemampuan berpikir kritis. Kemampuan berpikir kritis ini penting untuk membantu mahasiswa dalam memilih dan memilah informasi dengan baik, mengemukakan pendapat atau alasan, serta dapat memecahkan masalah. Berdasarkan hal tersebut di atas penelitian ini bertujuan untuk mengetahui pengaruh model pembelajaran Experiential Learning terhadap kemampuan pemecahan masalah mahasiswa.

\section{METODE}

Rancangan penelitian ini tergolong penelitian eksperimen semu (quasi experiment). Penelitian ini dilakukan untuk mengetahui pengaruh Experiential Learning terhadap kemampuan pemecahan masalah dan motivasi belajar mahasiswa geografi. Pada penelitian ini terdapat dua kelas dengan perlakuan berbeda. Kelas eksperimen diberi perlakuan Experiential Learning dalam pembelajarannya, sedangkan kelas kontrol tidak diberi perlakuan. Penelitian pada kedua kelas tersebut menggunakan rancangan pretest-posttest control design.

Subjek penelitian ini adalah Mahasiswa Geografi Universitas Negeri Malang Angkatan 2016/2017 yang mengikuti Mata Kuliah Geografi Lingkungan Teknik pengambilan sampel dilakukan dengan purposive sampling yang dipilih dengan pertimbangan tertentu. Penentuan kelas eksperimen dan kelas kontrol didasarkan pada jurusan dan kelas yang mengikuti matakuliah Geografi Lingkungan pada semester ganjil, yaitu Offering A dan Offering L.

Instrumen yang digunakan adalah catatan observasi, dokumentasi, dan soal esai kemampuan pemecahan masalah yang terdiri atas lima butir soal. Tujuan penggunaan instrumen soal esai adalah untuk mengukur tingkat kemampuan pemecahan masalah mahasiswa sebelum mengikuti kegiatan pembelajaran (pre-test) dan sesudah mengikuti kegiatan pembelajaran (posttest). Soal pre-test dan post-test diujicobakan pada kelas yang bukan merupakan bagian dari sampel penelitian. Pengujian instrumen penelitian soal pretest dan posttest, meliputi uji validitas dan reliabilitas. Analisis data yang digunakan antara lain uji prasyarat, meliputi uji normalitas dan homogenitas serta uji hipotesis dengan menggunakan Uji t.

\section{HASIL DAN PEMBAHASAN}

Kemampuan pemecahan masalah mahasiswa sebelum dan sesudah penerapan model pembelajaran Experiential Learning di kelas eksperimen dan kelas kontrol dijabarkan pada tabel 1 dan 2. 
Tabel 1. Distribusi Frekuensi Kemampuan Pemecahan Masalah Awal (Pretest) dan Akhir (Posttest) Kelas Eksperimen

\begin{tabular}{cccccc}
\hline \multirow{2}{*}{ Nilai } & \multirow{2}{*}{ Kualifikasi } & \multicolumn{2}{c}{ Pretest } & \multicolumn{2}{c}{ Posttest } \\
\cline { 3 - 6 } & & Frekuensi & Persentase (\%) & Frekuensi & Persentase (\%) \\
\hline $91-100$ & Sangat baik & 0 & 0 & 6 & 16,66 \\
$80-90$ & Baik & 0 & 0 & 23 & 63,89 \\
$65-79$ & Cukup & 13 & 36,11 & 7 & 19,44 \\
$50-64$ & Kurang & 17 & 47,22 & 0 & 0 \\
$<50$ & Sangat Kurang & 6 & 16,67 & 0 & 0 \\
\hline \multicolumn{2}{c}{ Jumlah } & 36 & 100 & 36 & 100 \\
\hline Mean & \multicolumn{3}{c}{58,56} & & 85,22 \\
\\
Median & 57,50 & & 85,00 \\
\hline
\end{tabular}

Tabel 1 menunjukkan kemampuan pemecahan masalah mahasiswa di kelas eksperimen sebelum dan setelah pelaksaanaan pembelajaran Experiential Learning. Mahasiswa dengan kemampuan awal (pretest) yang masuk dalam kategori sangat kurang sebanyak 16,67\%, kategori kurang sebanyak 47,22\%, dan kategori cukup sebanyak 36,11\%. Nilai rata-rata (mean) mahasiswa sebesar 58,56 dan median sebesar 57,50. Mahasiswa dengan kemampuan akhir (posttest) yang masuk dalam kategori cukup sebanyak $19,44 \%$, kategori baik sebanyak $63,89 \%$, dan kategori sangat baik sebanyak $16,66 \%$. Nilai rata-rata (mean) mahasiswa sebesar 85,22 dan median sebesar 85,00.

Tabel 2. Distribusi Frekuensi Kemampuan Pemecahan Masalah (Pretest) dan Akhir (Posttest) Kelas Kontrol

\begin{tabular}{cccccc}
\hline \multirow{2}{*}{ Nilai } & \multirow{2}{*}{ Kualifikasi } & \multicolumn{2}{c}{ Pretest } & \multicolumn{2}{c}{ Posttest } \\
\cline { 3 - 6 } & & Frekuensi & Persentase (\%) & Frekuensi & Persentase (\%) \\
\hline $91-100$ & Sangat baik & 0 & 0 & 1 & 3,12 \\
$80-90$ & Baik & 1 & 3,12 & 18 & 56,25 \\
$65-79$ & Cukup & 10 & 31,25 & 13 & 40,63 \\
$50-64$ & Kurang & 16 & 50,00 & 0 & 0 \\
$<50$ & Sangat Kurang & 5 & 15,66 & 0 & 0 \\
\hline \multicolumn{2}{c}{ Jumlah } & 32 & 100 & 32 & \\
\hline & Mean & 59,50 & & 80,09 \\
& Median & 60,00 & & \\
\end{tabular}

Tabel 2 menunjukkan kemampuan pemecahan masalah mahasiswa di kelas kontrol sebelum dan setelah pembelajaran tanpa penerapan Experiential Learning. Mahasiswa dengan kemampuan awal (pretest) yang masuk dalam kategori sangat kurang sebanyak $15,66 \%$, kategori kurang sebanyak 50\%, kategori cukup sebanyak 31,25\%, dan kategori baik sebanyak 3,12\%. Nilai rata-rata (mean) mahasiswa sebesar 59,50 dan median sebesar 60,00. Mahasiswa dengan kemampuan akhir (posttest) yang masuk dalam kategori cukup sebanyak 40,63\%, kategori baik sebanyak 56,25\%, dan kategori sangat baik sebanyak $3,12 \%$. Nilai ratarata (mean) mahasiswa sebesar 78,09 dan median sebesar 80,00.

Kemampuan pemecahan masalah mahasiswa diukur dengan menggunakan soal pretest dan posttest masing-masing berupa lima soal esai yang disusun berdasarkan lima indikator kemampuan pemecahan masalah, yaitu merumuskan masalah, merumuskan hipotesis, mengumpulkan data, menarik kesimpulan, dan merekomendasikan pemecahan masalah. Perubahan ratarata nilai pretest dan postesat ditunjukkan dengan perolehan gain score yang dijabarkan pada tabel 3.

Tabel 3. Perubahan Rata-rata Nilai Pretest dan Posttest

\begin{tabular}{clcccc}
\hline No. & \multicolumn{1}{c}{ Kelas } & Pretest & Posttest & Gain score & Persentase Peningkatan \\
\hline 1. & Eksperimen (Offering L) & 58,56 & 85,22 & 26,66 & 45,52 \\
2. & Kontrol (Offering A) & 59,50 & 78,09 & 18,59 & 31,24 \\
\hline
\end{tabular}

Berdasarkan tabel 3, dapat diketahui bahwa penerapan model pembelajaran Experiential Learningdi kelas eksperimen berhasil. Hal tersebut ditunjukkan dengan perubahan nilai pretest dari 58,56 menjadi 85,22 pada saat posttest dengan gain score sebesar 26,66 dan persentase peningkatan sebesar 45,52\%. Peningkatan nilai pretest di kelas kontrol yang awalnya lebih besar dari kelas eksperimen yaitu sebesar 59,50 meningkat menjadi 78,09 pada saat posttest dengan gain score sebesar 18,59 dan persentase peningkatan sebesar 31,24\%. Gain score dan persentase peningkatan nilai pada kelas eksperimen lebih besar dibandingkan kelas kontrol, Jadi, dapat disimpulkan bahwa model pembelajaran Experiential Learning membuat peningkatan 
rata-rata kemampuan pemecahan masalah mahasiswa lebih tinggi. Experiential Learning merupakan proses pembentukan pengetahuan yang memungkinkan mahasiswa untuk menyentuh keempat aspek dasar dalam belajar, yaitu mengalami, merefleksikan, berpikir, dan melakukan tindakan terkait dengan isu yang dipelajari. Model pembelajaran ini memungkinkan mahasiswa untuk membentuk keterampilan dan konstruksi pengetahuannya melalui pengalaman (Chesimet, 2016). Pengalaman konkret dijadikan sebagai dasar untuk melakukan observasi dan refleksi. Hasil dari refleksi dicerna dan diproses menjadi konsep abstrak yang kemudian dikembangkan menjadi implikasi untuk pengambilan tindakan dalam pemecahan suatu permasalahan. Tahapan model Experiential Learning (Kolb, 1984) yang diduga berpengaruh terhadap kemampuan pemecahan masalah mahasiswa adalah sebagai berikut.

Pertama, pengalaman konkret (Concrete Experience). Pada tahap ini, mahasiswa diarahkan untuk membentuk pengalaman nyatanya melalui kegiatan observasi di lapangan. Pemberian pengalaman nyata kepada mahasiswa digunakan untuk mengembangakan pembelajaran berbasis pemecahan masalah, sehingga mampu membangkitkan ketertarikan mahasiswa untuk menyelidiki lebih lanjut (Sholihah et al., n.d.). Mahasiswa selanjutnya mulai mengidentifikasi permasalahan lingkungan yang ada berdasarkan pengamatan singkat tersebut dan mulai membuat dugaan sementara terkait mengapa permasalahan itu dapat terjadi. Kemampuan pemecahan masalah mahasiswa mulai dikembangkan dalam tahap ini, yaitu pada indikator merumuskan masalah dan merumuskan hipotesis.

Mahasiswa mengidentifikasi permasalahan lingkungan berupa pencemaran sungai di DAM Kadalpang Malang dan merumuskan hipotesis terkait apa yang menjadi penyebab permasalahan lingkungan tersebut. Masing-masing kelompok memiliki hipotesis berbeda. Kelompok 1, 3, dan 4 menduga bahwa penyebab pencemaran sungai adalah limbah padat dari kegiatan domestic, seperti plastik, kardus, dan perabotan rumah tangga bekas. Hal ini ditunjukkan dengan adanya tumpukan limbah padat tersbut di beberapa titik sungai dengan jumlah yang cukup banyak. Kelompok 2 dan 5 menduga bahwa pencemaran sungai utamanya disebabkan oleh limbah cair kimia dan padatan tersuspensi dari kegiatan industri yang ditunjukkan dengan keruhnya air sungai dengan warna hijau kehitaman. Dalam dalam tahap ini mahasiswa masih belum mengetahui secara pasti mengenai faktor-faktor apa yang menyebabkan permasalahan tersebut terjadi dan bagaimana prosesnya, sehingga dibutuhkan kegiatan observasi reflektif untuk mengumpulkan data atau bukti lebih lanjut dari berbagai sumber yang digunakan sebagai dasar untuk menjawab hipotesis yang telah dirumuskan.

Kedua, observasi reflektif (Reflective Observation). Pada tahap observasi reflektif, mahasiswa melakukan transformasi pengalamannya dengan cara mencermati kembali dan memahami pengalaman yang didapatkan dari aktivitasnya dengan kegiatan refleksi. Proses refleksi menjadi dasar proses pemahaman konsep yang mendasari pengalaman yang dialami serta perkiraan kemungkinan aplikasinya dalam situasi atau konteks yang lain (Istighfaroh, 2014). Proses pemahaman tersebut dilakukan melalui kegiatan pengumpulan data dan diskusi. Masing-masing anggota dalam setiap kelompok secara aktif mengemukakan gagasangagasan penyebab pencemaran sungai berdasarkan berbagai bukti logis yang telah dikumpulkan. Bukti-bukti tersebut berupa data yang diperoleh dari lapangan maupun data yang yang diperoleh dari sumber lain, seperti buku dan jurnal yang berhubungan dengan kerusakan lingkungan, khususnya tentang pencemaran air.

Mahasiswa melakukan pengumpulan data melalui pengukuran dan pengamatan indikator pencemaran air, yaitu (1) $\mathrm{pH}$ air yang diukur dengan kertas $\mathrm{pH}$, (2) suhu yang diukur dengan termometer air raksa, (3) perubahan warna, bau, dan rasa yang diamati menggunakan panca indera, (4) kekeruhan yang diamati dengan memasukkan air sungai ke dalam wadah berupa gelas plastik, dan (5) kesadahan yang diamati dengan buih sabun deterjen. Berdasarkan pengumpulan data yang dilakukan oleh lima kelompok, maka indikator pencemaran air sungai yang didapatkan dapat disimpulkan pada tabel 4.

Tabel 4. Data Observasi Berupa Indikator Pencemaran Air

\begin{tabular}{ll}
\hline Indikator Pencemaran Air & \multicolumn{1}{c}{ Hasil Pengukuran/ Pengamatan } \\
\hline $\mathrm{pH}$ & 7 \\
$\mathrm{Suhu}$ & $\begin{array}{l}26-29{ }^{\circ} \mathrm{C}, \text { lebih rendah dibanding suhu udara } \\
\text { sekitar yaitu } 29-32^{\circ} \mathrm{C}\end{array}$ \\
Fisik & hijau kecoklatan \\
a. Warna & sedikit anyir \\
b. Bau & netral, tidak memiliki rasa \\
c. Rasa & rendah, sinar matahari masih dapat menembus \\
Kekeruhan & air \\
& rendah, sabun menghasilkan buih cukup banyak \\
\hline
\end{tabular}


Mahasiswa mendiskusikan data dari sumber primer yang dikumpulkan dari lapangan pada tabel 4 dan menyimpulkan bahwa kondisi pencemaran air di DAM Kadalpang masih tergolong rendah memiliki pH normal, suhu normal, warna, bau dan rasa normal, serta memiliki kekeruhan dan kesadahan yang rendah. Akan tetapi kondisi sungai yang kotor oleh tumpukan sampah di beberapa titik menyebabkan pencemaran yang berasal dari polutan berupa limbah padat domestik seperti plastik, kardus, dan perabotan rumah tangga bekas. Hal tersebut memberikan dampak buruk terhadap lingkungan karena beresiko mengganggu kesehatan masyarakat di sekitar sungai, menimbulkan bau tidak sedap, dan merusak keindahan lingkungan permukiman.

Tahap konseptualisasi abstrak dilakukan oleh mahasiswa dengan membuat kesimpulan berdasarkan hasil refleksi observatif yang telah dilakukan. Kesimpulan dibentuk menjadi konsep yang didasarkan pada pengujian hipotesis terhadap fakta yang ada di lapangan. Pada tahap ini, mahasiswa diharapkan mampu menjelaskan konsep terkait dengan permasalahan yang diamati serta mengintegrasikan pengalaman yang diperoleh dengan pengetahuan awal (Lestari, Sadia, \& Suma, 2014). Mahasiswa membuat kesimpulan berupa konsep yang diabstraksi dari pengalaman dari kegiatan observasi yang dapat diaplikasikan pada permasalahan serupa.

Setelah menyelesaikan tahap-tahap Experiential Learning sebelumnya melalui kegiatan observasi, mahasiswa melanjutkan pembelajaran dengan kegiatan diskusi bersama kelompok masing-masing. Kegiatan diskusi ini bertujuan untuk menguji hipotesis yang mereka buat terkait penyebab pencemaran air sungai. Diskusi dilakukan secara klasikal bersama seluruh kelompok dengan membandingkan dugaan sementara terkait penyebab pencemaran sungai dengan data yang dikumpulkan dari lapangan. Dugaan sementara yang dikemukakan oleh mahasiswa pada awal pembelajaran adalah bahwa pencemaran air sungai disebabkan oleh (1) limbah padat domestik berupa sampah plastik, kardus, perabotan rumah tangga bekas dan (2) limbah cair kimia dan padatan tersuspensi dari kegiatan industri. Berdasarkan data yang diambil dari lapangan dapat disimpulkan bahwa kondisi pencemaran air di DAM Kadalpang memang masih tergolong rendah, namun permasalahan utamanya adalah adanya tumpukan sampah di beberapa titik dengan jumlah yang cukup mengkhawatirkan.

Mahasiswa melanjutkan tahap konseptualisasi abstrak dengan diskusi secara lebih mendalam bersama kelompok masing-masing. Kegiatan diskusi tidak dapat dilanjutkan dalam kelas akibat keterbatasan waktu sehingga mahasiswa dipersilakan untuk melakukan diskusi secara lebih lanjut untuk memperdalam pengetahuan yang didapatkan melalui kegiatan observasi. Mahasiswa mencari data sekunder berupa referensi dari buku dan jurnal. Beberapa kelompok mengambil inisitif untuk mengumpulkan data tambahan berupa informasi dari wawancara singkat bersama warga yang tinggal di sekitar DAM Kadalpang sebagai pendukung untuk membantu mereka membuat kesimpulan. Kesimpulan yang didapatkan adalah bahwa penyebab utama pencemaran air sungai adalah adanya limbah padat domestik berupa sampah plastik, kardus, perabotan rumah tangga bekas yang menumpuk di beberapa titik. Hal tersebut terjadi akibat minimnya fasilitas kebersihan di sekitar, kurangnya kesadaran warga terhadap pentingnya pengelolaan sampah demi kebersihan sungai, dan rendahnya pengawasan pemerintah terhadap pelaksanaan peraturan terkait pengelolaan sampah domestik. Akibatnya adalah kondisi sekitar sungai yang menjadi kotor, menimbulkan bau tidak sedap, dan merusak keindahan lingkungan.

Secara umum, model Experiential Learning memberikan pengaruh terhadap kemampuan pemecahan masalah mahasiswa, yaitu dalam indikator menarik kesimpulan. Experiential Learning mengajak mahasiswa untuk memandang secara kritis kejadian yang ditemui dalam kehidupan sehari-hari mengetahui apa yang sebenarnya terjadi kemudian menarik kesimpulan sebagai salah satu bentuk pemahaman (Munif \& Mosif, 2009). Pemahaman mahasiswa didapatkan dari abstraksi konsep dari pengalaman kegiatan obserbasi yang selanjutnya digunakan sebagai dasar untuk pemecahan masalah.

Penerapan Experiential Learning dalam penelitian ini bertujuan agar mahasiswa dapat menggunakan pengalaman konkret untuk pemecahan suatu permasalahan. Hal tersebut sesuai dengan pernyataan teori Lewin bahwa pengalaman konkret adalah dasar dari observasi dan refleksi untuk kemudian diasimilasi menjadi sebuah teori dan/atau konsep yang digunakan sebagai pemandu pengambilan tindakan atau pemecahan masalah (Kolb, 1984). Pengalaman konkret yang dimiliki mahasiswa dijadikan sebagai dasar pengambilan keputusan untuk memecahkan permasalahan yang disajikan. Kemampuan pemecahan masalah mahasiswa dalam indikator merekomendasikan pemecahan masalah dikembangkan pada tahap terakhir Experiential Learning, yaitu tahap eksperimental aktif.

Kegiatan yang dilakukan pada tahap eksperimentasi aktif bertujuan untuk mahasiswa agar lebih menguasai pemahamannya dengan menguji konsep yang diabstraksi untuk menjelaskan pengalaman atau situasi problematik baru. Eksperimentasi aktif dalam tahap ini dilakukan dengan pemberian permasalahan baru yang masih berhubungan dengan permasalahan yang disajikan sebelumnya, yaitu terkait pencemaran air sungai. Dosen membagian jurnal dengan tema pencemaran air kepada masing-masing kelompok untuk kemudian mereka review dalam sebuah diskusi. Mahasiswa bersama kelompoknya masing-masing merumuskan permasalahan yang dijabarkan dalam jurnal, merumuskan hipotesis, mengumpulkan data yang relevan dan menarik kesimpulan dengan mengaitkan data dengan hipotesis yang mereke rumuskan. Selanjutnya, masing-masing kelompok mempresentasikan solusi terbaik untuk mengatasi permasalahan yang mereka temukan dalam jurnal. 
Penerapan Experiential Learning meningkatkan kemampuan pemecahan masalah mahasiswa. Melalui model pembelajaran ini, mahasiswa diajak untuk mampu mengimplementasikan hasil konstruksinya dalam kehidupan nyata sehari-hari atau dalam bentuk penyelesaian masalah (Latipah, 2016). Kegiatan Experiential Learning menjadikan pengalaman konkret sebagai sumber pembelajaran untuk membentuk pengetahuannya sendiri dan menggunakan pengetahuan tersebut untuk merumuskan pemecahan dari suatu permasalahan.

\section{SIMPULAN}

Model pembelajaran Experiential Learning berpengaruh signifikan terhadap kemampuan pemecahan masalah mahasiswa. Pengalaman konkret yang didapatkan secara langsung di lapangan melalui kegiatan observasi menjadi dasar bagi mahasiswa untuk mengembangkan kemampuan berpikirnya untuk memecahkan permasalahan nyata yang terjadi di lingkungan sekitarnya. Hal ini didukung dengan data perolehan gain score kelas eksperimen yang menerapkan model pembelajaran Experiential Learning lebih tinggi daripada kelas kontrol yang menerapkan model pembelajaran konvensional berupa ceramah.

Peneliti dapat mengembangkan penelitian eksperimen selanjutnya terkait Experiential Learning secara lebih komprehensif. Penelitian selanjutnya dapat meneliti mengenai penerapan Experiential Learning terhadap literasi geografi mahasiswa. Pada pelaksanaan Experiential Learning dalam penelitian ini mahasiswa mengumpulkan data baik dari primer maupun sekunder sehingga penelitian selanjutnya dapat mengembangkan penelitian ke arah literasi geografi. Penggunaan Lembar Kerja Mahasiswa penting untuk disusun secara detail guna menunjang kegiatan dan mengasah kemampuan pemecahan masalah mahasiswa di lapangan.

\section{DAFTAR RUJUKAN}

Chesimet, M. C. (2016). Effects of Experiential Learning Approach on Students' Mathematical Creativity among Secondary School Students of Kericho East Sub-County, Kenya. Journal of Education and Practice, 7(23), 51-57.

Istighfaroh, Z. (2014). Pelaksanaan Model Pembelajaran Experiental Learning di Pendidikan Dasar Sekolah Alam Anak PrimaYogyakarta. Jurnal Teknologi Pendidikan Universitas Negeri Yogyakarta. http://journal.student.uny.ac.id/ojs/index.php/fiptp/article/download/143/136

Jogiyanto. (2006). Pembelajaran Metode Kasus untuk Dosen dan Mahasiswa. Yogyakarta: Andi.

Kolb, D. A. (1984). Experiential Learning: Experience as a Source of Learning and Development. New Jersey: Prentice Hall.

Kolb, A. Y., \& Kolb, D. A. (2005). Learning Styles and Learning Spaces: Enhancing Experiential Learning in Higher Education. Academy of Management Learning \& Education, 4(2), 193-212.

Kumara, A. (2004). Active Learning Mata Pelajaran Sains Tingkat SD Kota Yogyakarta sebagai Upaya Peningkatan Life Skills. Jurnal Psikologi, 31(2), 63-91.

Latipah, E. (2016). Pengaruh Strategi Experiential Learning terhadap Self-Regulated Learning Mahasiswa. Humanitas, 14(1), 4156.

Lestari, N. W. R., Sadia, I. W., \& Suma, K. (2014). Pengaruh Model Experiential Learning terhadap Keterampilan Berpikir Kritis dan Motivasi Berprestasi Siswa. Jurnal Pendidikan dan Pembelajaran IPA Indonesia, 4(1).

Munif, I. R. S. \& Mosif. (2009). Penerapan Metode Experiential Learning pada Pembelajaran IPA untuk Meningkatkan Hasil Belajar. Jurnal Pendidikan Fisika Indonesia, 5(2), 79-82.

Mustika, F. (2015). Pengaruh Model Pembelajaran Experiential Learning terhadap Kemampuan Berpikir Kritis Mahasiswa. Tesis tidak diterbitkan. Universitas Negeri Malang, Malang.

Sholihah, M., Utaya, S., \& Susilo, S. (2016). Pengaruh Model Experiential Learning terhadap Kemampuan Berpikir Siswa SMA. Jurnal Pendidikan: Teori, Penelitian, dan Pengembangan, 1(11), 2096-2100. 